Agro-Science Journal of Tropical Agriculture, Food, Environment and Extension Volume 18 Number 3 (January 2020) pp. 25 - 30

ISSN 1119-7455

\title{
EFFECT OF DIETARY SUPPLEMENTATION OF VITAMINS C AND E ON THE SEMEN QUALITY OF LOCAL TURKEYS
}

\author{
Uzochukwu I.E., *Amaefule B.C. and Ugwu S.O.C. \\ Department of Animal Science, Faculty of Agriculture, University of Nigeria, Nsukka, Nigeria \\ *Corresponding author's email: bright.amaefule@unn.edu.ng
}

\begin{abstract}
A 56-day study was conducted to evaluate the effect of dietary supplementation of vitamins $\boldsymbol{C}$ and $\boldsymbol{E}$ on semen quality of local toms. Twenty-four toms were procured and randomly divided into four groups $\left(T_{1}, T_{2}, T_{3}\right.$ and $\left.T_{4}\right)$ of six birds each and replicated thrice. Birds in $T_{I}$ (control) were fed diets without vitamin supplementation. Birds in $T_{2}, T_{3}$ and $T_{4}$ were fed diets supplemented with Vitamin $C(400 \mathrm{mg})$, Vitamin $E$ (125 mg), and vitamin $E(125 \mathrm{mg})+$ Vitamin C (400 $\mathrm{mg})$ in a $\mathrm{kg}$ diet, respectively. Semen collections and evaluations were done through to the 8th week. The samples were evaluated for ejaculate volume, progressive sperm motility (mot.), sperm concentration (SC), percentage live (LSP) and dead spermatozoa, and total sperm per ejaculate. Results showed that all semen quality traits considered differed $(P<0.01)$ among the treatment groups. Toms in T4 had the highest $(P<0.01)$ values of mot. $(88.08 \%)$ and LSP $(85.23 \%)$. The $T_{2}$ and $T_{3}$ groups had similar mot. (75.39 and $77.15 \%$, respectively) and $L S P$ (71.81 and $76.80 \%$, respectively) values while the control group had the least values $\left(54.13\right.$ and $54.69 \%$, respectively). The $S C\left(x 10^{9} / \mathrm{ml}\right)$ was highest in $T_{4}$ (17.42). Toms in $T_{3}$ had a higher SC level (14.03) than those of the $T_{2}$ (11.58) and the control (8.92). It was concluded therefore, that combined supplementation of vitamins $E(125 \mathrm{mg} / \mathrm{kg}$ diet) and C (400 mg/kg diet) in toms' diet enhanced semen quality the most and thus, recommended for turkey breeding operations.
\end{abstract}

Key words: Toms, semen quality, vitamin $\mathrm{C}$ and vitamin $\mathrm{E}$

\section{INTRODUCTION}

Poultry farming is a measure in alleviating poverty and addressing the menace of protein insufficiency among many households in sub-Saharan Africa, particularly, Nigeria (Dim et al., 2018). Poultry has been adjudged the fastest and preferred source of animal protein compared to other livestock and its production offers the highest turnover rate and the quickest returns to investment outlay in the livestock enterprises (Osokomaiya and Talabi, 2003; Sanni and Ogundipe, 2005). According to the FLDPCS' (1992) estimate, local chicken alone constitute $69 \%$ of the total poultry production in Nigeria with turkey, guinea fowl, ducks, and pigeon also contributing significantly. The turkey industry in Nigeria contributes up to 1.5-2 million tonnes of meat per year (Mbanasor and Sampson, 2004). This evident improvement in the growth in the industry was made possible by intensification of production of both indigenous and exotic breeds with standard weight ranging from 15 to $17 \mathrm{~kg}$ for males and 8 to $10 \mathrm{~kg}$ for females. In most third world countries, intensive turkey production has been hampered by low number of poults produced. Egg yields in turkeys are considered to be lower than those of other poultry species. In addition to low egg yield, unsatisfactory egg fertility and hatchability constitute a major problem for turkey breeding enterprises
(Ozcelik et al., 2009). This problem is also felt with the indigenous breeds that produce their poults mostly by natural mating. Male turkeys (toms) are known to be rather clumsy when it comes to mating to produce fertile eggs. This suggests that natural mating may not be the best means of generating turkey poults for increased turkey production.

Turkey producers in especially the developed countries use artificial insemination to facilitate rapid generation of poults. Amidst fertility problems experienced in turkey production, the use of artificial insemination in this regard is not popular in Nigeria. One problem in artificial insemination of turkey includes the production of significant number of viable sperm to ensure effective breeding of a good number of hens. The avian semen contains high concentrations of polyunsaturated fatty acids (PUFAs) which is associated with increased proliferation of reactive oxygen species (ROS) and lipid peroxidation in sperm (Golzar Adabi et al., 2011; Alizadeh et al., 2016). When ROS is higher than the natural antioxidant defense mechanisms, the sperm will be damaged by lipid peroxidation and later can result in lowered fertility (Long and Kramer, 2003). Normally, spermatozoa are protected from ROS and lipid peroxidation by various antioxidants and enzymes present in seminal plasma (Min et al., 2016). 
Antioxidants have important roles in avian reproduction. Vitamin $\mathrm{E}$ is a major natural lipid soluble antioxidant present in cell membranes which inhibits free radical induced peroxidation and is capable of enhancing semen quality and fertilizing capacity (Cerolini et al., 2006; Panda and Cherian, 2014; Rengaraj and Hong, 2015). Available information shows that dietary vitamin E supplementation of balanced poultry ration significantly supports reproductive functions, including semen volume, sperm concentration, sperm viability, sperm motility, and sperm cell integrity, in avian species (Khan et al., 2012; Rakha et al., 2015; Rengaraj and Hong, 2015). Vitamin E is getting substantial interest in poultry feeding due to its key- role as a dietary antioxidant to prevent oxidative stress (Dhama et al., 2014).

Vitamin C on the other hand is a water soluble vitamin with the ability to prevent reactive oxygen species (ROS). In seminal plasma, its level is 10 times greater than serum and its concentration is positively correlated with the sperm morphology and functions (Yousef et al., 2003). Vitamin C has been known to improve semen quality in poultry species. Nowaczewski and Kontecka (2005) documented that vitamin $\mathrm{C}$ contributes $65 \%$ of the antioxidant capacity of the seminal plasma. Dobrescu (1987) demonstrated that supplementation of vitamin $\mathrm{C}$ at the rate of $150 \mathrm{ppm}$ increases semen volume, sperm concentration and total number of sperms produced in male turkey breeder. Improved semen quality and fertility were also reported with vitamin $\mathrm{C}$ supplementation in male broiler breeders (McDaniel et al., 1998).

Information in literatures has shown that vitamins $\mathrm{E}$ and $\mathrm{C}$ can facilitate increased sperm production in males of various farm animal species. However there is paucity of information on the combined effects of these two vitamins on the semen quality of turkey toms. This study is therefore aimed at evaluating the comparative effect of vitamin $\mathrm{E}$ and vitamin $\mathrm{C}$ and their combination on semen quality traits of local turkey toms.

\section{MATERIALS AND METHODS}

Location and duration of the study

The study was carried out at the Poultry Unit of the Department of Animal Science Teaching and Research Farm, University of Nigeria, Nsukka. The study lasted for a period of 8 weeks.

\section{Management of experimental animals}

Twenty-four (24) mature local broad breasted turkey toms (Meleagris gallopavo) of similar sizes and weight $(6.42 \pm 0.82)$ were procured and used for the study. The toms were sourced from a reputable Turkey farm (Okonkwo Farms) in Ekwulobia, Anambra State, Nigeria. The toms were randomly divided into four (4) treatment groups $\left(\mathrm{T}_{1}, \mathrm{~T}_{2}, \mathrm{~T}_{3}\right.$, and $\left.\mathrm{T}_{4}\right)$ of six birds each in a
Completely Randomized Design (CRD). Each treatment was replicated three times with two birds per replicate. Toms in $T_{1}$ served as the control group and were fed basal diet without any supplementation. Toms in $\mathrm{T}_{2}, \mathrm{~T}_{3}$ and $\mathrm{T}_{4}$ were fed with the basal diets supplemented with $125 \mathrm{mg}$ Vitamin E; $400 \mathrm{mg}$ Vitamin C; and combined 125 mg Vitamin $\mathrm{E}+400 \mathrm{mg}$ Vitamin $\mathrm{C}$, respectively in a $\mathrm{kg}$ diet. The toms were housed and managed in a deep litter system and were kept in separate experimental pens according to their respective replicates. Feed and water were supplied to the birds ad libitum. On arrival, anti-stress drug (Gentaryl D) was administered to them via the drinking water. During the pre-experimental period, they were vaccinated against common bacterial and viral infections and also dewormed after two weeks with piperazine.

\section{Experimental Diet}

Four experimental diets were formulated and compounded for the study. Diet 1 the basal diet had no supplemental inclusions of vitamins $\mathrm{E}$ and $\mathrm{C}$ and this served as the diet for the control group $\left(\mathrm{T}_{1}\right)$. Birds in $\mathrm{T}_{2}$ received the basal diet supplemented with $125 \mathrm{mg}$ Vitamin $\mathrm{E} / \mathrm{kg}$ diet. The $\mathrm{T}_{3}$ group received diet supplemented with $400 \mathrm{mg}$ of Vitamin $\mathrm{C} / \mathrm{kg}$ diet. Birds in $\mathrm{T}_{4}$ received diets supplemented with $400 \mathrm{mg}$ of vitamin $\mathrm{C}$ and $125 \mathrm{mg}$ of vitamin $\mathrm{E}$ per $\mathrm{kg}$ diet. The percentage composition of the experimental diets is shown in Table 1.

Table 1: Nutrient composition of the experimental diet per $100 \mathrm{~kg}$

\begin{tabular}{|c|c|c|c|c|}
\hline Ingredients (Kg) & $\mathrm{T}_{1}$ (Control) & $\mathrm{T}_{2}$ & $\mathrm{~T}_{3}$ & $\mathrm{~T}_{4}$ \\
\hline Maize & 25.89 & 25.89 & 25.89 & 25.89 \\
\hline Sorghum & 19.42 & 19.42 & 19.42 & 19.42 \\
\hline Wheat offal & 19.42 & 19.42 & 19.42 & 19.42 \\
\hline Palm kernel cake & 6.07 & 6.07 & 6.07 & 6.07 \\
\hline Groundnut cake & 10.93 & 10.93 & 10.93 & 10.93 \\
\hline Fish meal & 0.48 & 0.48 & 0.48 & 0.48 \\
\hline Soya bean meal & 6.80 & 6.80 & 6.80 & 6.80 \\
\hline Lime stone & 4.0 & 4.0 & 4.0 & 4.0 \\
\hline Bone meal & 5.0 & 5.0 & 5.0 & 5.0 \\
\hline Methionine & 0.5 & 0.5 & 0.5 & 0.5 \\
\hline Lysine & 0.5 & 0.5 & 0.5 & 0.5 \\
\hline Salt & 0.5 & 0.5 & 0.5 & 0.5 \\
\hline Premix & 0.5 & 0.5 & 0.5 & 0.5 \\
\hline Total & 100 & 100 & 100 & 100 \\
\hline Vitamin E (mg) & 0 & 125 & 0 & 125 \\
\hline vitamin $\mathrm{C}(\mathrm{mg})$ & 0 & 0 & 400 & 400 \\
\hline \multicolumn{5}{|c|}{$\begin{array}{l}\text { *Each } 1 \mathrm{~kg} \text { of premix contains: } 10,000 \mathrm{IU} \text { vitamin (vit.) A; } \\
2,500 \mathrm{IUvit} . \mathrm{D} 3 ; 20 \mathrm{mg} \text { vit. E; } 3 \mathrm{mg} \text { vit. } \mathrm{K} 3 ; 2 \mathrm{mg} \text { thiamine; } 5 \\
\text { mg riboflavine; } 5 \mathrm{mg} \text { pyridoxine; } 0.015 \mathrm{mg} \text { vit. B12; } 40 \mathrm{mg} \\
\text { Nicotinicacid; } 12 \mathrm{mg} \text { Pantothenicacid; } 0.75 \mathrm{mg} \text { folicacid; } \\
0.05 \mathrm{mg} \text { biotine; } 100 \mathrm{mg} \text { Vit. C; } 70 \mathrm{mg} \text { manganese } / \mathrm{kg} ; 60 \mathrm{mg} \\
\text { zinc } / \mathrm{kg} ; 60 \mathrm{mg} \text { iron } / \mathrm{kg} ; 1 \mathrm{mg} \text { iodine } / \mathrm{kg} ; 8 \mathrm{mg} \text { copper } / \mathrm{kg} ; 0.25 \\
\mathrm{mg} \text { selenium } / \mathrm{kg} ; \text { and } 0.15 \mathrm{mg} \text { cobalt } / \mathrm{kg} \text {. }\end{array}$} \\
\hline
\end{tabular}




\section{Semen Collection and Evaluation}

Semen collection and evaluation were done twice weekly for 8 weeks following stabilization and training of the birds. Semen was collected from the toms using the abdominal manual massage method as described by Al-Daraji (2007). Individual ejaculates were collected using a $4 \mathrm{ml}$ graduated collection tube and the semen volumes were directly read off to the nearest $0.1 \mathrm{ml}$. The determination of the different physical characteristics of the semen was made as described by Peter et al. (2008). The percentage motility of spermatozoa was evaluated immediately after semen collection. For this, a drop of semen was placed on a warm glass slide and covered with a cover slip to evenly spread the semen in the slide.

The slide was afterwards viewed in the microscope (400x magnifications). Observations were widely made across different areas on the slide for the various samples. Motility was judged as the proportion of sperm cells that were motile in the various observations made. Sperm concentration was determined by the method of direct cell count using an improved Neubauer hemocytometer. The percentages of live and dead spermatozoa were determined using an eosin-nigrosin stained smear with oil emulsion and observed under a light microscope at $400 \times$ magnification. Unstained spermatozoa were regarded as live whereas stained or partially stained spermatozoa were counted as dead. This determination was made over observations of about 200 spermatozoa per slide.

\section{Statistical Analysis}

The data generated were analysed using one way analysis of variance (ANOVA) in SPSS software (IBM® version 20.0). Differences found among the treatment means were compared using Duncan's New Multiple Range Test (Duncan, 1955) and accepted at $5 \%$ or $1 \%$ level of probability.

\section{RESULTS}

The results of the effect of dietary supplementation of vitamins $\mathrm{C}$ and $\mathrm{E}$ on the semen characteristics of turkey toms are presented in Table 2 . The results showed that there were differences $(P<0.01)$ in all the measured semen characteristics of volume; Progressive sperm motility (\%); sperm concentration $\left(\times 10^{9} / \mathrm{ml}\right)$; percentage live and dead sperm cells; and total sperm cells ( $\times 10^{9} /$ ejaculation.) among the treatment groups. The semen volume was observed to be similar for toms in $\mathrm{T}_{3}(125 \mathrm{mg}$ of Vit. E/ $\mathrm{kg}$ diet $)$ and $\mathrm{T}_{4}(400 \mathrm{mg}$ of Vit. C+125 mg of Vit. E / kg diet) groups $(0.20$ and $0.22 \mathrm{ml}$, respectively). These values were higher than those obtained for $T_{2}(400$ $\mathrm{mg}$ of Vit. $\mathrm{C} / \mathrm{kg}$ diet) and $\mathrm{T}_{1}$ (control) which had similar values $(0.12 \mathrm{ml}$, respectively). For the percentage progressive sperm motility, $\mathrm{T}_{4}$ had a value which was higher $(P<0.01)$ than those of the other groups. Toms in $\mathrm{T}_{2}$ and $\mathrm{T}_{3}$ had similar $(P \geq 0.01)$ values of sperm motility which were higher $(P<0.01)$ than that of the control group. The $\mathrm{T}_{4}$ group was found to have higher $(P<0.01)$ levels of both semen concentration and total sperm cells than those of the other groups. Higher $(P<0.01)$ values of semen concentration and total sperm cells were obtained for $T_{3}$ than those observed for $T_{2}$ and the control group. The values obtained for the $\mathrm{T}_{2}$ and the control groups were however found to be similar $(P \geq 0.01)$ to each other. The percentage live sperm cells of toms were highest in the $\mathrm{T}_{4}$ group $(85.23 \%)$. This was higher $(P<0.01)$ than those of the other groups. However, the toms in $\mathrm{T}_{2}$ and $\mathrm{T}_{3}$ groups had similar values of live sperm cells (71.81 and $76.80 \%$, respectively) which were higher $(P<0.01)$ than those of the control group (54.69\%).

\section{DISCUSSION}

The results showed that supplementation of the toms' diet with vitamin $\mathrm{C}$ improved $(P<0.01)$ the percentage progressive sperm motility as well as live

Table 2. The effect of vitamin C and E supplementation on semen characteristics of turkey Toms

\begin{tabular}{|c|c|c|c|c|c|}
\hline Parameters & $\begin{array}{c}\mathrm{T} 1 \\
\text { Control }\end{array}$ & $\begin{array}{c}\mathrm{T} 2 \\
\text { Vitamin C } \\
(400 \mathrm{mg})\end{array}$ & $\begin{array}{c}\mathrm{T} 3 \\
\text { Vitamin E } \\
(125 \mathrm{mg})\end{array}$ & $\begin{array}{c}\mathrm{T} 4 \\
\text { Vitamin C }(400 \mathrm{mg}) \\
\text { and Vitamin E }(125 \mathrm{mg})\end{array}$ & P Value \\
\hline Volume (ml) & $0.12 \pm 0.02^{\mathrm{b}}$ & $0.12 \pm 0.02^{b}$ & $0.20 \pm 0.02^{\mathrm{a}}$ & $0.22 \pm 0.02^{\mathrm{a}}$ & $* *$ \\
\hline Prog. Sperm. Mot. (\%) & $54.13 \pm 5.81^{\mathrm{c}}$ & $75.39 \pm 7.11^{\mathrm{b}}$ & $77.15 \pm 5.81^{\mathrm{b}}$ & $88.08 \pm 7.11^{\mathrm{a}}$ & $* *$ \\
\hline $\begin{array}{l}\text { Sperm Conc. } \\
\left(\mathrm{x} 10^{9} / \mathrm{ml}\right)\end{array}$ & $8.92 \pm 1.09^{\mathrm{c}}$ & $11.58 \pm 1.34^{\mathrm{c}}$ & $14.03 \pm 1.09^{\mathrm{b}}$ & $17.42 \pm 1.34^{\mathrm{a}}$ & $* *$ \\
\hline $\begin{array}{l}\text { Live sperm cells } \\
(\%)\end{array}$ & $54.69 \pm 5.12^{\mathrm{c}}$ & $71.81 \pm 6.27^{\mathrm{b}}$ & $76.80 \pm 5.12^{\mathrm{b}}$ & $85.23 \pm 6.27^{\mathrm{a}}$ & $* *$ \\
\hline $\begin{array}{l}\text { Dead sperm cells } \\
(\%)\end{array}$ & $45.31 \pm 2.10^{\mathrm{a}}$ & $28.19 \pm 2.57^{\mathrm{b}}$ & $23.20 \pm 2.11^{\mathrm{b}}$ & $14.77 \pm 2.57^{\mathrm{c}}$ & $* *$ \\
\hline $\begin{array}{l}\text { Total sperm } \\
\text { cells }\left(\times 10^{9} / \mathrm{Ejac}\right)\end{array}$ & $1.08 \pm 0.34^{\mathrm{c}}$ & $1.38 \pm 0.41^{\mathrm{c}}$ & $2.81 \pm 0.34^{\mathrm{b}}$ & $3.83 \pm 0.41^{\mathrm{a}}$ & $* *$ \\
\hline
\end{tabular}


spermatozoa when compared to those of the control group. Similar to our findings, reports of improvements in the semen quality of poultry species have been documented (McDaniel et al., 1998; Khan et al., 2012). Neuman et al. (2002) reported that supplementation of Ascorbic acid by up to $300 \mathrm{mg} / \mathrm{kg}$ diet in the diet of male turkey breeders did not affect the semen quality indices of volume, sperm concentration, dead spermatozoa, as well as the size of testes. Also, contrary to the findings of this study, Ascorbic acid did not improve sperm motility, viability and membrane integrity in the semen of turkey toms as reported by Donoghue and Donoghue (1997). Supplementation of Ascorbic acid (up to $200 \mathrm{mg} / \mathrm{kg}$ diet) in the diets of breeder turkey toms have also been shown to improve semen volume and concentration (Dobrescu, 1987; Noll, 1993), an observation that is contrary to what we recorded in the present study. The improvement observed in the sperm motility and live and dead spermatozoa of the $\mathrm{T}_{2}$ toms when compared to the control group could be attributed to the antioxidative properties of Ascorbic acid. It is known that the membranes of the avian spermatozoa often contain high concentration of polyunsaturated fatty acid (PUFA) and that this attribute of the membranes makes them very sensitive to lipid peroxidation. The antioxidant vitamin $\mathrm{C}$ (Ascorbic acid) is inherently found in both the spermatozoa and the seminal plasma as stated by Surai et al. (2001). Ascorbic acid has been documented to protect the DNA of spermatozoa from oxidative damages (by scavenging reactive oxygen species, ROS) with a resultant preservation of the integrity of the spermatozoa membranes and genes (Fraga et al., 1991; Luck et al., 1995). This phenomenon is thus the likely reason for the observed improvement in percentage sperm motility and live spermatozoa.

Vitamin E administrations to poultry have been commonly known to markedly improve reproduction and productivity in general (Surai, 1999). Supplementation of vitamin E in the diet of turkey toms was observed to improve all the semen quality parameters considered in the present study. These results are in line with the reports of Gorgy (2013) who documented a marked improvement in the semen quality traits of sperm concentration, sperm viability, and sperm motility in toms by vitamin E. Several other reports of improvement in reproductive functions as well as semen quality in poultry species have also been recorded (Franchini, et al., 2001; Lin et al., 2005; Biswas et al., 2009; Rakha et al., 2015; Rengaraj and Hong, 2015). The generation of reactive oxygen species has been implicated in alterations in the fluidity of sperm membranes; DNA and protein damages; and a resultant reduction in sperm motility and fertility (Lopes et al., 1998; Sanocka and Kurpisz, 2004).
Just like VC, VE is also an important natural antioxidant in the semen of chicken and turkey and has been commonly referred to as the anti-sterility vitamin (Shamma et al., 2016). Thus to sustain the production of viable and fertile sperm cells, it is necessary to ensure that the antioxidant complex protects the PUFA rich sperm membranes from lipid peroxidation and the likely resultant impairment of sperm cells and fertility loss (Sura1 et al., 1997). According to Surai et al. (2001), the concentration of $\mathrm{VE}$ is higher in the spermatozoa than in the seminal fluid. This enhancement in the semen quality of turkey toms observed in our study could possibly stem from the anti-oxidative role of VE in limiting lipid peroxidation in spermatozoa membranes. According to Cerolini et al. (2000), VE limits oxidative damages in cells through their scavenging actions on the toxic free radicals (particularly reactive oxygen species, ROS). In addition to this, Surai et al. (2001) reported that VE can also cause an increase in the superoxide dismutase and glutathione. Hence the semen quality improvement capacity of VE is attributable to its ability to enhance the efficiency of antioxidant system and consequently meliorate oxidative stress in the sperm cells with a resultant maintenance of the optimum fertilizing capacity as stated by Shamma et al. (2016). Better semen quality was obtained with VE supplementation than with VC. This report is in line with that of Yousef et al. (2003) and Massaeli et al. (1999) who stated that VE was a more efficient antioxidant than VC.

The combined supplementation of vitamins $C$ and $\mathrm{E}$ (in $\mathrm{T}_{4}$ group) was observed to improve semen quality the most. Toms in $\mathrm{T}_{4}$ performed better than those of the $\mathrm{T}_{3}$ (Vitamin $\mathrm{E}$ alone) and other groups in the semen indices of Progressive motility, Sperm concentration, total sperm cells, and the percentage live sperm cells. This observed marked improvement could be attributed to a possible synergistic effect of the both vitamins ( $\mathrm{C}$ and $\mathrm{E}$ ) to achieve a better antioxidant protective role for the spermatozoa. Similar to our findings, Min et al. (2016) reported a decrease in the oxidative stress markers in the serum, semen and testes; as well as an increase in serum testosterone levels and semen quality indices in induced dexameth as one stressed breeder roosters when VC and VE are fed combined than individually in the diet. Several other reports of improvement in semen quality with combined supplementation of VE and other antioxidants such as selenium and fatty acids have been documented (Ebeid, 2012; Surai, 2002; Agarwal et al., 2005). According to Padayatty et al. (2003), VC represents a very integral part of the antioxidant system in the extracellular space. It can cause a reduction of ferric $\left(\mathrm{Fe}^{3+}\right)$ to ferrous ions $\left(\mathrm{Fe}^{2+}\right)$ ions; an enhancement in the anti-oxidative status of the serum (Whitehead and Keller, 2003), Semen (Martínez-Páramo et al., 2012), 
testes (Ashamu et al., 2010); and an improvement in the antioxidant activities of VE. This could be the reason for the observed better performance of the toms fed the combined VC and VE supplementation when compared to the individual supplementations of the respective vitamins in this study.

\section{CONCLUSION}

In conclusion, this present study showed that though individual supplementation of either VC or VE improved semen quality, combined supplementation of the two Vitamins ( $\mathrm{C}$ and $\mathrm{E}$ ) produced a better quality semen in turkey toms. Therefore combined dietary supplementation of vitamins $\mathrm{C}$ and $\mathrm{E}$ can be used to improve reproductive performance particularly in turkey breeding programmes.

\section{REFERENCES}

Agarwal A., Prabakaran S.A. and Said T.M. (2005). Prevention of oxidative stress injury to sperm. Journal of Andrology, 26, 654-660

Al-Daraji H.J. (2007). Artificial insemination in domestic birds. Ministry of Higher Education and Scientific Research, Univ of Baghdad, College of Agriculture, Baghdad, Iraq

Alizadeh A., Taleb Z., Ebrahimi B., Esmaeili V., Shaverdi A., Nasr J. and Yazdi R.S. (2016). Dietary Vitamin $\mathrm{E}$ is more effective than Omega-3 and Omega-6 fatty acid for improving the kinematic characteristics of rat sperm. Cell Journal (Yakhteh), 18 (2), 262-270

Ashamu E.A., Salawu E.O., Oyewo O.O., Alhassan A.W., Alamu O.A. and Adegoke A.A. (2010). Efficacy of vitamin C and ethanolic extract of Sesamum indicum in promoting fertility in male Wistar rats. Journal of Human Reproductive Science, 3, 11

Biswas A., Mohan J. and Sastry K.V. (2009). Effect of higher dietary vitamin $\mathrm{E}$ concentrations on physical and biochemical characteristics of semen in Kadaknath cockerels. British Poultry Science, 50, 733-738

Cerolini S., Maldljian A., Surai P. and Noble R. (2000). Viability, susceptibility to peroxidation and fatty acid composition of boar semen during liquid storage. Animal Reproduction Science, 58, 99-111

Cerolini, S., Zaniboni, L. and Maldjian, A. (2006). Effect of docosahexaenoic acid and $\alpha$-tocopherol enrichment in chicken sperm on semen quality, sperm lipid composition and susceptibility to peroxidation. Theriogenology, 66 (4), 877-886

Dhama K., Tiwari R., Khan R.U., Chakraborty S., Gopi M., Karthik K., Saminathan M., Desingu P.A. and Sunkara L.T. (2014). Growth promoters and novel feed additives improving poultry production and health, bioactive principles and beneficial applications: The trends and advances- A Review. International Journal of Pharmacology, 10, 129-159. DOI: 10.3923/ijp.2014.129.159

Dim C.E., Akuru E.A., Egom M.A., Nnajiofor N.W., Ossai O.K., Ukaigwe C.G. and Onyimonyi A.E. (2018).Effect of dietary inclusion of biochar on growth performance, haematology and serum lipid profile of broiler birds. Agro-Science, 17 (2), 8-16. DOI: https://dx.doi.org/10.4314/as.v17i2.2
Dobrescu O. (1987). Vitamin C addition to breeder diets increase turkey semen production. Feedstuffs, 59, 18

Donoghue A.M. and Donoghue D.J. (1997). Effects of water and lipid soluble antioxidants on turkey sperm viability, membrane integrity and motility during lipid storage. Poultry Science, 76, 1440-1445

Duncan D.B. (1955). Multiple range and multiple F tests, Biometrics, 11, 1-42

Ebeid T.A. (2012). Vitamin E and organic selenium enhances the antioxidative status and quality of chicken semen under high ambient temperature. British Poultry Science, 53 (5), 708-714

Federal Department of Livestock and Pest Control Services (FDLPCS) (1992). Nigerian National Livestock Survey. Federal Ministry of Agriculture Lagos, Nigeria

Fraga C.G., Motchnik P.A., Shigenaga M.K., Helbock H.J., Jacob R.A. and Ames B.N. (1991). Ascorbic acid protects against endogenous oxidative DNA damage in human sperm. Proceedings of the National Academy of Science, 88, 11003-11006

Franchini A., Bergonzoni M.L. and Melotti C. (2001). The effect of dietary supplementation with high doses of vitamin $\mathrm{E}$ and $\mathrm{C}$ on the quality traits of chicken semen. Arch Geflugelkd, 65, 76-81

GolzarAdabi S.H., Cooper R.G., Kamali M.A. and Hajbabaei A. (2011). The influence of inclusions of vitamin $\mathrm{E}$ and corn oil on semen traits of Japanese quail (Coturnixcoturnix japonica). Animal Reproduction Science, 123 (12), 119-125

Gorgy M.A.L. (2013). Some Managerial Factors Affecting Productive Performance in Turkeys. MSc thesis, Faculty of Agriculture Mansoura University, Egypt

Khan R.U., Rahman Z.U., Javed I. and Muhammad F. (2012). Effect of vitamins, probiotics and protein on semen traits in post-molt male broiler breeders. Animal Reproduction Science, 135, 85-90

Lin Y.F., Chang S.J., Yang J.R., Lee Y.P. and Hsu A.L. (2005). Effect of supplemental vitamin E during the mature period on the reproductive performance of Taiwan Native Chicken cockerels. British Poultry Science, 46, 366-373

Long J.A. and Kramer M. (2003). Effect of vitamin E on lipid peroxidation and fertility after artificial insemination with liquid-stored Turkey semen. Poultry Science, 82, 1802-1807

Lopes S., Jurisicova A., Sun J.G. and Casper R.F. (1998). Reactive oxygen species: potential cause for DNA fragmentation in human spermatozoa. Human Reproduction, 13, 896-900

Luck M.R., Jeyaseelan I. and Scholes R.A. (1995). Minireview: Ascorbic acid and fertility. Biology of Reproduction, 52, 262-266

Martínez-Páramo S., Diogo P., Dinis M.T., Herráez M.P., Sarasquete C. and Cabrita E. (2012). Incorporation of ascorbic acid and $\alpha$-tocopherol to the extender media to enhance antioxidant system of cryopreserved sea bass sperm. Theriogenology, 77, 1129-1136

Massaeli H., Sobrattee S. and Pierce G.N. (1999). The importance of lipid solubility in antioxidants and free radical generating systems for determining lipoprotein peroxidation. Free Radical Bioliogy and Medicine, 26, $1524-1530$

Mbanasor J.A. and Sampson A. (2004). Socio-economic Determinants of turkey production among Nigerian soldiers. Int. Journal of Poultry Science, 3 (8), 497-502 
McDaniel C.D., Hannah J.L., Parker H.M., Smith T.W., Schultz C.D. and Zumwalt C.D. (1998). Use of a sperm quality analyzer for evaluating broiler breeder males: effects of altering sperm quality and quantity on the sperm motility index. Poultry Science 77, 888-893.

Min Y., Sun T., Niu Z. and Liu F. (2016). Vitamin C and vitamin $\mathrm{E}$ supplementation alleviates oxidative stress induced by dexamethasone and improves fertility of breeder roosters. Animal Reproduction Science. doi:10.1016/j.anireprosci.2016.04.005

Min Y., Sun T., Niu Z. and Liu F. (2016). Vitamin C and vitamin $\mathrm{E}$ supplementation alleviates oxidative stress induced by dexamethasone and improves fertility of breeder roosters. Animal Reproduction Science. doi: http://dx.doi.org/10.1016/j.anireprosci.2016.04.005

Neuman S.L., Orban J.I., Lin T.L., Latour M.A. and Hester P.Y. (2002). The effect of dietary ascorbic acid on semen traits and testis histology of male turkey breeders. Poultry Science, 81, 265-268

Noll S. (1993). Personal communication to Tillman P.B. Feed Management, 44 (10), 31

Nowaczewski S. and Kontecka H. (2005). Effect of dietary vitamin $\mathrm{C}$ supplement on reproductive performance of aviary pheasants. Czech Journal of Animal Science, 50, 208-212

Osokomaiya A.A. and Talabi A.O. (2003). Wood ash as a preservative for table egg. Effect on albumin height, yolk index and weight loss. Proceedings of $28^{\text {th }}$ Annual Conference of Nigerian Society for Animal Production, pp. 88-91

Ozcelik M., Ekmen F. and Elmaz O. (2009). Effect of location of eggs in the incubator on hatchability of eggs from Bronze turkey breeders of different ages. South African Journal of Animal Science, 39, 214-222

Padayatty S.J., Katz A., Wang Y., Eck P., Kwon O., Lee J., Chen S., Corpe C., Dutta A., Dutta S.K. et al. (2003). Vitamin C as an antioxidant: evaluation of its role in disease prevention. Journal of the American College of Nutrition, 22, 18-35

Panda A.K. and Cherian G. (2014). Role of vitamin E in counteracting oxidative stress in poultry. Journal of Poultry Science, 51, 109-117

Peters S.O., Shoyebo O. D., IIori B.M., Ozoje M.O., Ikeobi C.O.N. and Adebambo O.A. (2008). Semen quality traits of seven strains of chickens raised in the humid tropics. International Journal of Poultry Science 7 (10), 949-953

Rakha B.A., Ansari M.S., Hussain I., Malik M.F., Akhter S. and Blesbois E. (2015). Semen characteristics of the
Indian Red Jungle Fowl (Gallus gallusmurghi). European Journal of Wildlife Research, 61, 379-386

Rengaraj D.and Hong Y.H. (2015). Effects of dietary Vitamin $\mathrm{E}$ on fertility functions in poultry species. Int. Journal of Molecular Sciences, 16, 9910-9921

Sahin K. and Kucuk O. (2001). Effects of vitamin E and selenium on performance, digestibility of nutrients, and carcass characteristics of Japanese quails reared under heat stress $\left(34\right.$ degrees $\left.{ }^{\circ} \mathrm{C}\right)$. Journal of Animal Physiology and Animal Nutrition 85, 342-348

Sanni S.A. and Ogundipe S.O. (2005). Economics of some modules of poultry production in Kaduna State, Nigeria. Nigerian Journal of Animal Production, 32 (1), 102-107

Sanocka D. and Kurpisz M. (2004). Reactive oxygen species and sperm cells. Biology of Reproduction 2, 12

Shamma T.A., Samia Z.M., Samya E.I. and El-Aik M.A. (2016). Effect of Omega-3 sources and Vitamin E supplementation in the turkey toms diet on semen characteristics and fertilizing ability. Animal and Poultry Production, 7 (3), 101-111

Statistical Packages for the Social Sciences (SPSS) (2001). Statistical Software for Windows Version 11_0 Microsoft. Chicago, IL, USA

Surai P.F., Kutz E., Wishart, G.J., Noble R.C. and Speake B.K. (1997). The relationship between the dietary provision of alpha-tocopherol and the concentration of this vitamin in the semen of chicken: effects on lipid composition and susceptibility to peroxidation. Journal of Reproduction \& Fertility, 110, 47-51

Surai P.F., Fujihara N., Speake B.K., Brillard J.P., Wishart G.J. and Sparks N.H.C. (2001). Polyunsaturated fatty acids, lipid peroxidation and antioxidant protection in avian semen-Review. AsianAustralian Journal of Animal Science, 14, 1024-1050

Surai P.F. (1999). Vitamin E in avian reproduction. Poultry and Avian Biology Review, (10), 1-60

Surai P.F. (2002). Selenium in poultry nutrition 2. reproduction, egg and meat quality and practical applications. World's Poultry Sci. Journal, 58, 431-450

Whitehead C.C. and Keller T. (2003). An update on ascorbic acid in poultry. World Poultry Science Journal, 59, 161-184

Yousef M.I., Abdallah G.A. and Kamel K.I. (2003). Effect of ascorbic acid and Vitamin E supplementation on semen quality and biochemical parameters of male rabbits. Animal Reproduction Science, 76, 99-111 